\title{
DECREASE IN BENEFITS FOR DISABILITY IN RHEUMATOID ARTHRITIS. A NATIONWIDE STUDY FROM
} 2004 TO 2017

Zilcem Arruda-Júnior (Universidade de Brasília, Brasília, DF, Brasil), Ana Paula Gomides (Universidade de Brasília, Brasília, DF, Brasil), Josierton Bezerra (Universidade de Brasília, Brasília, DF, Brasil), Luciana Muniz (Hospital Regional de Sobradinho, Brasília, DF, Brasil), Leopoldo Luiz Santos-Neto (Hospital Universitário de Brasília, Brasília, DF, Brasil), Licia Maria Henrique Mota (Universidade de Brasília, Brasília, DF, Brasil)

\section{BACKGROUND}

Rheumatoid arthritis (RA) is a chronic systemic inflammatory disease that, if not treated properly, may lead to irreversible joint sequels. In addition to the serious impacts on the patient itself, rheumatoid arthritis can affect society as a whole, either through expenses related to its direct care or indirectly by affecting the patients' work capacity, rendering them temporarily or permanently incapacitated, which generates high social security costs for the payment of benefits to those people who are early away from work. Objectives: To evaluate the laboral incapacity by the RA in Brazil, analyzing the benefits for withdrawals of work by Social Security.

\section{MATERIALS AND METHODS}

A cross-sectional retrospective study that analyzed the social security benefits granted by the National Social Security Institute (INSS) from 2004 to 2017. Official data from the public administration through the E-SIC portal were analyzed for temporary and permanent withdrawal (retirements due to disability) by the ICD10 M05, M06 and variants.

\section{RESULTS}

A total of 30.662 .276 social security benefits due to diseases in general were granted by the INSS in the period analyzed. $123.982(0.4 \%)$ were attributed to rheumatoid arthritis, $81.8 \%$ were due to temporary laboral incapacity and $18.2 \%$ were retirement pensions. The distribution of these benefits per year was analyzed. In 2004 a total of 13.263 benefits were granted by RA and in 2017 this number was 7.378 concessions. The evolution of the percentage of benefits by RA in relation to the total can be seen in figure 1.

\section{CONCLUSION}

In Brazil, rheumatoid arthritis is still responsible for a significant portion of the social security benefits granted to sick people, however, there has been an absolute and relative decrease in the granting of these benefits for this disease over the last years, which may represent an improvement in its treatment and prognosis in our country. 